Canadian University Music Review

Canadian University Music Review

Revue de musique des universités canadiennes

Carl Morey. Music in Canada: A Research and Information

Guide. New York and London: Garland Publishing, 1997. Music

Research and Information Guides, vol. 20; Garland Reference

Library of the Humanities, vol. 1823. xiii, 283 pp. ISBN

0-8153-1603-8 (hardcover)

\title{
Lisa Philpott
}

Volume 19, numéro 1, 1998

URI : https://id.erudit.org/iderudit/1014608ar

DOI : https://doi.org/10.7202/1014608ar

Aller au sommaire du numéro

Éditeur(s)

Canadian University Music Society / Société de musique des universités

canadiennes

ISSN

0710-0353 (imprimé)

2291-2436 (numérique)

Découvrir la revue

Citer ce compte rendu

Philpott, L. (1998). Compte rendu de [Carl Morey. Music in Canada: A Research and Information Guide. New York and London: Garland Publishing, 1997. Music Research and Information Guides, vol. 20; Garland Reference Library of the Humanities, vol. 1823. xiii, 283 pp. ISBN 0-8153-1603-8 (hardcover)]. Canadian University Music Review / Revue de musique des universités canadiennes, 19(1), 85-85. https://doi.org/10.7202/1014608ar

All Rights Reserved (C Canadian University Music Society / Société de musique des universités canadiennes, 1998
Ce document est protégé par la loi sur le droit d'auteur. L'utilisation des services d'Érudit (y compris la reproduction) est assujettie à sa politique d'utilisation que vous pouvez consulter en ligne.

https://apropos.erudit.org/fr/usagers/politique-dutilisation/ 
Carl Morey. Music in Canada: A Research and Information Guide. New York and London: Garland Publishing, 1997. Music Research and Information Guides, vol. 20; Garland Reference Library of the Humanities, vol. 1823. xiii, 283 pp. ISBN 0-8153-1603-8 (hardcover).

Originally conceived as a much larger work by the late George Proctor, this volume by Carl Morey, Professor of Music at the University of Toronto and the holder of the Jean A. Chalmers Chair in Canadian Music, fills a void in Canadian music bibliography. It is comprehensive, current and well organized. Each of the thirteen sections (Reference; Catalogues and Directories; History and Criticism; Musicians-Biographies and Individual Studies; Native Music; Folk and Ethnic Music; Popular Music and Jazz; Education; Media; Commerce; Periodicals; Archives and Collections) is prefaced by a concise introduction; larger sections are divided logically, with the entries organized alphabetically by author.

Did we need another bibliography of Canadian music? Most definitely. Although there has been a proliferation of bibliographies written about Canadian music, many of them have become dated; others have a narrow focus (e.g., Canadian repertoire for the free base accordion). Morey has given us a wideranging overview, replete with succinct and useful annotations. Could we have wished for more? Certainly we might have wished for a larger section devoted to popular music and jazz. We might also wish that he had been less selective (but not at the risk of delaying the publication of the present volume): Morey states in his introduction that he chose "to provide significant titles of works on most Canadian musical topics" rather than give us an exhaustive study (p. $x$ ). We can all admire (and covet) the comprehensive holdings of the University of Toronto libraries, which facilitated Morey's research.

Music in Canada lists 928 items; each entry provides a complete bibliographic citation (including ISBN/ISSN where available); each of the 928 items is annotated, which is remarkable. There are three separate indexes: title, author/editor, and subject. Set in a readable font with judicious use of bolded headings, there are a number of "orphans" (e.g., p. 116, "Pauline Donalda" where the accompanying citation and annotation are separated from the heading) which are distracting. But this is a minor flaw in an otherwise exceptional reference work.

Essential for music libraries and for those libraries which support a Canadian Studies programme. 